\title{
Deep neuromuscular block reduces the incidence of intra-operative complications during laparoscopic donor nephrectomy: a pooled analysis of randomized controlled trials
}

Gabby T. J. A. Reijnders-Boerboom ${ }^{1,2^{*}+}$ (D), Esmee V. van Helden ${ }^{1,2+}$, Robert C. Minnee ${ }^{3}$, Kim I. Albers ${ }^{1,2}$, Moira H. D. Bruintjes ${ }^{1}$, Albert Dahan ${ }^{4}$, Chris H. Martini ${ }^{4}$, Frank C. H. d'Ancona ${ }^{5}$, Gert-Jan Scheffer ${ }^{2}$, Christiaan Keijzer ${ }^{2}$ and Michiel C. Warlé

\begin{abstract}
Study objective: To assess whether different intensities of intra-abdominal pressure and deep neuromuscular blockade influence the risk of intra-operative surgical complications during laparoscopic donor nephrectomy.

Design: A pooled analysis of ten previously performed prospective randomized controlled trials.

Setting: Laparoscopic donor nephrectomy performed in four academic hospitals in the Netherlands: Radboudumc, Leiden UMC, Erasmus MC Rotterdam, and Amsterdam UMC.

Patients: Five hundred fifty-six patients undergoing a transperitoneal, fully laparoscopic donor nephrectomy enrolled in ten prospective, randomized controlled trials conducted in the Netherlands from 2001 to 2017.

Interventions: Moderate (tetanic count of four $>1$ ) versus deep (post-tetanic count 1-5) neuromuscular blockade and standard $(\geq 10 \mathrm{mmHg})$ versus low $(<10 \mathrm{mmHg})$ intra-abdominal pressure.

Measurements: The primary endpoint is the number of intra-operative surgical complications defined as any deviation from the ideal intra-operative course occurring between skin incision and closure with five severity grades, according to Classintra. Multiple logistic regression analyses were used to identify predictors of intra- and postoperative complications.
\end{abstract}

\footnotetext{
* Correspondence: gabby.reijnders-boerboom@radboudumc.nl

Gabby T.J.A. Reijnders-Boerboom and Esmee V. van Helden are shared first authors.

${ }^{\dagger}$ Gabby T. J. A. Reijnders-Boerboom and Esmee V. van Helden contributed equally to this work.

'Department of Surgery, Radboud University Medical Centre, Geert Grooteplein Zuid 10, 6525, GA, Nijmegen, The Netherlands

${ }^{2}$ Department of Anaesthesiology, Radboud University Medical Centre, Geert Grooteplein Zuid 10,6525, GA, Nijmegen, The Netherlands

Full list of author information is available at the end of the article
}

C C The Author(s). 2021 Open Access This article is licensed under a Creative Commons Attribution 4.0 International License, which permits use, sharing, adaptation, distribution and reproduction in any medium or format, as long as you give appropriate credit to the original author(s) and the source, provide a link to the Creative Commons licence, and indicate if changes were made. The images or other third party material in this article are included in the article's Creative Commons licence, unless indicated otherwise in a credit line to the material. If material is not included in the article's Creative Commons licence and your intended use is not permitted by statutory regulation or exceeds the permitted use, you will need to obtain permission directly from the copyright holder. To view a copy of this licence, visit http://creativecommons.org/licenses/by/4.0/ The Creative Commons Public Domain Dedication waiver (http://creativecommons.org/publicdomain/zero/1.0/) applies to the data made available in this article, unless otherwise stated in a credit line to the data. 
Main results: In 53/556 (9.5\%) patients, an intra-operative complication with ClassIntra grade $\geq 2$ occurred. Multiple logistic regression analyses showed standard intra-abdominal pressure $(O R 0.318,95 \% \mathrm{Cl} 0.118-0.862 ; p=0.024)$ as a predictor of less intra-operative complications and moderate neuromuscular blockade (OR 3.518, 95\% Cl 1.2449.948; $p=0.018$ ) as a predictor of more intra-operative complications. Postoperative complications occurred in 31/ $556(6.8 \%)$, without significant predictors in multiple logistic regression analyses.

Conclusions: Our data indicate that the use of deep neuromuscular blockade could increase safety during laparoscopic donor nephrectomy. Future randomized clinical trials should be performed to confirm this and to pursue whether it also applies to other types of laparoscopic surgery.

Trial registration: Clinicaltrials.gov LEOPARD-2 (NCT02146417), LEOPARD-3 trial (NCT02602964), and RELAX-1 study (NCT02838134), Klop et al. (NTR 3096), Dols et al. 2014 (NTR1433).

Keywords: Intra-operative complications, Postoperative complications, Laparoscopy, Artificial pneumoperitoneum, Neuromuscular blockade

\section{Introduction}

The use of deep neuromuscular blockade (NMB) defined as a post-tetanic count (PTC) of 1-2(Albers et al., 2019) may facilitate laparoscopic surgery for two reasons. First, surgical space conditions as rated by surgeons on a subjective scale from 1 to 5(Torensma et al., 2016) are significantly better in patients undergoing laparoscopic surgery with a deep NMB, as compared to a moderate NMB.(Bruintjes et al., 2017) The main component of surgical condition rating scale is the intra-abdominal working space. A few clinical studies indicate that the intra-abdominal working space is increased by using deep instead of moderate NMB.(Lindekaer et al., 2013; Van Wijk et al., 2015; Madsen et al., 2015) Secondly, deep NMB provides better surgical stillness as compared to moderate NMB (TOF 1-2)(Blobner et al., 2015), as on average the diaphragm is fully relaxed with a deep but not with a moderate block.(Pansard et al., 1987) Therefore, the use of deep NMB during laparoscopy may either enable the use of lower insufflation pressures or improve surgical conditions at standard intra-abdominal pressure. The use of low intraabdominal pressure (IAP) $(<10 \mathrm{mmHg})$ during laparoscopic surgery reduces abdominal pain, referred shoulder pain, and analgesic consumption as compared to standard pressure $(\geq 10 \mathrm{mmHg})$.(Warlé et al., 2013; Gurusamy et al., 2009; Özdemir-van Brunschot et al., 2016; Singla \& Mittal, 2014) Nevertheless, the use of low IAP is still under debate because it remains unclear if improved patient recovery outweighs a theoretically increased risk of intraoperative surgical complications related to limited working space. To assess whether different intensities of IAP and NMB influence the risk of intraoperative surgical complications, we performed a secondary analysis on ten randomized controlled trials in adults undergoing transperitoneal, fully laparoscopic donor nephrectomy.

\section{Material and methods \\ Ethics}

Approval for the four randomized controlled trials initiated by Radboudumc was given by the Central Committee on Research involving Human Subjects of the Radboud University Nijmegen Medical Center.(Warlé et al., 2013; Özdemir-van Brunschot et al., 2017; Özdemir-van Brunschot et al., 2018; Bruintjes et al., 2019) Approval for the five randomized controlled trials initiated by Erasmus MC Rotterdam was given by the Institutional Review Board of the Erasmus $\mathrm{MC}$ in Rotterdam.(Klop et al., 2014; Dols et al., 2014; Dols et al., 2010; Kok et al., 2006a; Kok et al., 2006b) One trial initiated by Amsterdam UMC was approved by the Medical Ethical Committee of the Academic Medical Center Amsterdam.(Minnee et al., 2008) Oral and written informed consent was obtained from all patients before inclusion.

\section{Pooled analysis}

We performed a secondary analysis on pooled data $(n=$ 556) of ten previously conducted prospective, doubleblinded randomized controlled trials (Table 1). The methods and primary outcomes of these trials(Warlé et al., 2013; Özdemir-van Brunschot et al., 2017; Özdemir-van Brunschot et al., 2018; Bruintjes et al., 2019; Klop et al., 2014; Dols et al., 2014; Dols et al., 2010; Minnee et al., 2008; Kok et al., 2006a; Kok et al., 2006b) in laparoscopic donor nephrectomy patients were previously published. All trials were initiated by Radboudumc, Erasmus MC Rotterdam, and Amsterdam UMC and performed in four academic teaching hospitals in the Netherlands from 2001 to 2017. Anesthesia and surgery were protocolized and similar, except for the depth of neuromuscular blockade, intra-abdominal pressure, and analgesia. Baseline characteristics such as type of anesthesia, gender, ASA classification, age, and body mass index (BMI) are presented in Table 1. 
Table 1 Trial overview and baseline characteristics

\begin{tabular}{|c|c|c|c|c|c|c|c|c|c|c|c|c|c|}
\hline & \multirow[t]{2}{*}{$\begin{array}{l}\text { Participating } \\
\text { centers }\end{array}$} & \multirow[t]{2}{*}{$\begin{array}{l}\text { Recruitment } \\
\text { period }\end{array}$} & \multirow{2}{*}{$\begin{array}{l}\text { Number } \\
\text { of } \\
\text { patients }\end{array}$} & \multirow[t]{2}{*}{$\begin{array}{l}\text { IAP } \\
(\mathrm{mmHg})\end{array}$} & \multirow[t]{2}{*}{$\begin{array}{l}\text { Type of } \\
\text { NMB }^{b}\end{array}$} & \multirow[t]{2}{*}{$\begin{array}{l}\text { Type of } \\
\text { anesthesia }\end{array}$} & \multicolumn{2}{|l|}{$\begin{array}{l}\text { Gender } \\
N(\%)\end{array}$} & \multicolumn{3}{|c|}{$\begin{array}{l}\text { ASA classification } \\
N(\%)\end{array}$} & \multirow{2}{*}{$\begin{array}{l}\text { Age } \\
\text { Mean } \\
\text { (SD) }\end{array}$} & \multirow{2}{*}{$\begin{array}{l}\text { BMI } \\
\text { Mean } \\
\text { (SD) }\end{array}$} \\
\hline & & & & & & & Male & $\overline{\text { Female }}$ & 1 & 2 & 3 & & \\
\hline $\begin{array}{l}\text { Warle et al. } \\
\text { (2013) }\end{array}$ & RUMC & $2011-2012$ & 20 & 7 vs 14 & TOF 1-2 & TIVA & $\begin{array}{l}10 \\
(50.0 \%)\end{array}$ & $\begin{array}{l}10 \\
(50.0 \%)\end{array}$ & $\begin{array}{l}17 \\
(85 \%)\end{array}$ & $\begin{array}{l}3 \\
(15 \%)\end{array}$ & $\begin{array}{l}0 \\
(0 \%)\end{array}$ & $\begin{array}{l}51.15 \\
( \pm \\
9.33)\end{array}$ & $\begin{array}{l}25.32 \\
( \pm \\
3.21)\end{array}$ \\
\hline $\begin{array}{l}\text { Ozdemir-Van } \\
\text { Brunschot } \\
\text { et al. (2017) }\end{array}$ & RUMC & 2014-2015 & 64 & 6 vs 12 & PTC 1-5 & Volatile & $\begin{array}{l}36 \\
(56.3 \%)\end{array}$ & $\begin{array}{l}28 \\
(43.8 \%)\end{array}$ & $\begin{array}{l}44 \\
(69 \%)\end{array}$ & $\begin{array}{l}20 \\
(31 \%)\end{array}$ & $\begin{array}{l}0 \\
(0 \%)\end{array}$ & $\begin{array}{l}54.94 \\
( \pm \\
12.04)\end{array}$ & $\begin{array}{l}25.92 \\
( \pm \\
3.19)\end{array}$ \\
\hline $\begin{array}{l}\text { Ozdemir-Van } \\
\text { Brunschot } \\
\text { et al. (2018) }\end{array}$ & RUMC & 2015-2016 & 34 & 6 & $\begin{array}{l}\text { TOF } 1-2 \\
\text { Vs PTC } 1- \\
5\end{array}$ & Volatile & $\begin{array}{l}22 \\
(64.7 \%)\end{array}$ & $\begin{array}{l}23 \\
(35.3 \%)\end{array}$ & N/A & N/A & N/A & $\begin{array}{l}50.19 \\
( \pm \\
12.49)\end{array}$ & $\begin{array}{l}25.54 \\
( \pm \\
3.74)\end{array}$ \\
\hline $\begin{array}{l}\text { Bruintjes et al. } \\
\text { (2019) }\end{array}$ & $\begin{array}{l}\text { RUMC } \\
\text { LUMC }\end{array}$ & 2016-2017 & 96 & 12 & $\begin{array}{l}\text { "Single- } \\
\text { dose" vs } \\
\text { PTC 1-2 }\end{array}$ & TIVA & $\begin{array}{l}45 \\
(46.9 \%)\end{array}$ & $\begin{array}{l}51 \\
(53.1 \%)\end{array}$ & $\begin{array}{l}61 \\
(64 \%)\end{array}$ & $\begin{array}{l}35 \\
(36 \%)\end{array}$ & $\begin{array}{l}0 \\
(0 \%)\end{array}$ & $\begin{array}{l}56.14 \\
( \pm \\
9.90)\end{array}$ & $\begin{array}{l}26.46 \\
( \pm \\
2.99)\end{array}$ \\
\hline $\begin{array}{l}\text { Klop et al. } \\
\text { (2014) }\end{array}$ & EMCR & $2011-2012$ & $20^{\mathrm{a}}$ & 14 & $\begin{array}{l}\text { "Single- } \\
\text { dose" }\end{array}$ & TIVA & $\begin{array}{l}5 \\
(25.0 \%)\end{array}$ & $\begin{array}{l}15 \\
(75.0 \%)\end{array}$ & $\begin{array}{l}14 \\
(70 \%)\end{array}$ & $\begin{array}{l}5 \\
(25 \%)\end{array}$ & $\begin{array}{l}1 \\
(5 \%)\end{array}$ & $\begin{array}{l}49.72 \\
( \pm \\
14.39)\end{array}$ & $\begin{array}{l}25.09 \\
( \pm \\
3.19)\end{array}$ \\
\hline $\begin{array}{l}\text { Dols et al. } \\
(2014)\end{array}$ & EMCR & $2008-2010$ & $95^{\mathrm{a}}$ & 14 & $\begin{array}{l}\text { "Single- } \\
\text { dose" }\end{array}$ & TIVA & $\begin{array}{l}39 \\
(41.1 \%)\end{array}$ & $\begin{array}{l}56 \\
(58.9 \%)\end{array}$ & $\begin{array}{l}59 \\
(62 \%)\end{array}$ & $\begin{array}{l}35 \\
(37 \%)\end{array}$ & $\begin{array}{l}1 \\
(1 \%)\end{array}$ & $\begin{array}{l}51.59 \\
( \pm \\
12.99)\end{array}$ & $\begin{array}{l}25.96 \\
( \pm \\
4.13)\end{array}$ \\
\hline $\begin{array}{l}\text { Dols et al. } \\
\text { (2010) }\end{array}$ & $\begin{array}{l}\text { EMCR } \\
\text { RUMC }\end{array}$ & $2006-2008$ & 40 & 12 & $\begin{array}{l}\text { "Single- } \\
\text { dose" }\end{array}$ & TIVA & $\begin{array}{l}24 \\
(60.0 \%)\end{array}$ & $\begin{array}{l}16 \\
(40.0 \%)\end{array}$ & $\begin{array}{l}29 \\
(73 \%)\end{array}$ & $\begin{array}{l}11 \\
(28 \%)\end{array}$ & $\begin{array}{l}0 \\
(0 \%)\end{array}$ & $\begin{array}{l}53.41 \\
( \pm \\
9.62)\end{array}$ & $\begin{array}{l}26.94 \\
( \pm \\
3.78)\end{array}$ \\
\hline $\begin{array}{l}\text { Minnee et al. } \\
\text { (2008) }\end{array}$ & AUMC & $2002-2006$ & 105 & 12 & $\begin{array}{l}\text { "Single- } \\
\text { dose" }\end{array}$ & TIVA & $\begin{array}{l}44 \\
(41.9 \%)\end{array}$ & $\begin{array}{l}61 \\
(58.1 \%)\end{array}$ & $\begin{array}{l}85 \\
(81 \%)\end{array}$ & $\begin{array}{l}20 \\
(19 \%)\end{array}$ & $\begin{array}{l}0 \\
(0 \%)\end{array}$ & $\begin{array}{l}47.73 \\
( \pm \\
11.86)\end{array}$ & $\begin{array}{l}25.61 \\
( \pm \\
3.57)\end{array}$ \\
\hline $\begin{array}{l}\text { Kok et al. } \\
(2006 a, b)\end{array}$ & EMCR & $2001-2004$ & $49^{a}$ & 12 & $\begin{array}{l}\text { "Single- } \\
\text { dose" }\end{array}$ & TIVA & $\begin{array}{l}25 \\
(51.0 \%)\end{array}$ & $\begin{array}{l}24 \\
(49.0 \%)\end{array}$ & $\begin{array}{l}39 \\
(80 \%)\end{array}$ & $\begin{array}{l}10 \\
(20 \%)\end{array}$ & $\begin{array}{l}0 \\
(0 \%)\end{array}$ & $\begin{array}{l}49.40 \\
( \pm \\
14.73)\end{array}$ & $\begin{array}{l}25.73 \\
( \pm \\
3.57)\end{array}$ \\
\hline $\begin{array}{l}\text { Kok et al. } \\
(2006 a, b)\end{array}$ & $\begin{array}{l}\text { EMCR } \\
\text { RUMC }\end{array}$ & $2001-2004$ & $50^{\mathrm{a}}$ & 12 & $\begin{array}{l}\text { "Single- } \\
\text { dose" }\end{array}$ & TIVA & $\begin{array}{l}18 \\
(52.9 \%)\end{array}$ & $\begin{array}{l}16 \\
(47.1 \%)\end{array}$ & N/A & N/A & N/A & $\begin{array}{l}47.31 \\
( \pm \\
13.23)\end{array}$ & $\begin{array}{l}26.13 \\
( \pm \\
4.45)\end{array}$ \\
\hline
\end{tabular}

RUMC Radboud University Medical Centre, LUMC Leiden University Medical Centre, EMCR Erasmus Medical Centre Rotterdam, AUMC Amsterdam University Medical Centre, TIVA total intravenous anesthesia, IAP intra-abdominal pressure, NMB neuromuscular blockade, ASA American Society of Anesthesiologists classification system, $B M I$ body mass index

a Number of patients who underwent laparoscopic donor nephrectomy (transperitoneal approach)

${ }^{\mathrm{b}}$ All studies used rocuronium as neuromuscular blocking agent

\section{Intra-operative complications}

The primary outcome measure was the number of intraoperative complications with a severity score of two or higher, according to the validated Classification of Intraoperative Complications (ClassIntra) score.(Kaafarani \& Velmahos, 2015; Rosenthal et al., 2015; Kinaci et al., 2016; Dell-Kuster et al., 2015; Dell-Kuster et al., 2020) This classification is a recently, well-validated classification system for intra-operative complications, featuring simple but inclusive definitions. The classification includes five severity grades depending on the need for treatment and degree of life-threat: with grade 1, a complication without symptoms and no need for treatment; grade 2, a complication with moderate symptoms and the need for additional treatment; grade 3, a complication with severe symptoms, potentially life-threatening, and the need for moderate additional treatment; grade 4, a complication with life-threatening symptoms and the need for major or urgent treatment; and grade 5, being fatal, leading to intra-operative death.(Dell-Kuster et al., 2020) In all studies, grade $\geq 2$ intra-operative complications were recorded prospectively.

\section{Outcomes}

Secondary outcome measures included operation time, estimated blood loss, 30-day postoperative complications, and length of hospital admission. Postoperative complications were recorded during the first thirty postoperative days and graded according to the ClavienDindo classification.(Dindo et al., 2004; Mitropoulos et al., 2018) The Clavien-Dindo scale varies from grade 1 , meaning every deviation from the normal postoperative course without the need for treatment; grade 2, meaning any deviation with the need for pharmacological treatment; grade 3, deviations requiring surgical, endoscopic, or radiological intervention, divided into 3- 
a, not under general anesthesia, and 3-b, under general anesthesia; grade 4, deviations leading to 4-a, single organ disfunction, and 4-b, multi-organ disfunction; to grade 5 , meaning death of a patient.

\section{Statistical analysis}

Multiple logistic regression analysis was performed for the intra- and postoperative complications as the dependent variable. Independent variables included in the logistic regression models were intra-abdominal pressure, neuromuscular block, age, gender, BMI, and trial year. Continuous variables were expressed as mean ( \pm standard deviation) and categorical data as number (percentage). All statistical analyses were performed with IBM SPSS Statistics (version 24, Armonk NY).

\section{Results}

\section{Intra- and postoperative surgical complications}

Intra- and postoperative outcomes are presented per randomized group in Tables 2 and 4. Of the 556 living donors, fifty-three (9.5\%) patients developed intraoperative complications graded $\geq 2$ according to ClassIntra. Chi-square analysis showed $p$ values $<0.05$ between the groups with different intra-abdominal pressures (group A vs. C: $p<0.001$, group B vs. D: $p=0.009$ ) and between standard IAP with deep NMB compared to low IAP with moderate NMB (group B vs. group C: $p<$ 0.001). No significance was present between standard
IAP with moderate $\mathrm{NMB}$ compared to low IAP with deep NMB (group A vs. group D: $p=0.076$ ) (Table 2).

Multiple logistic regression analysis revealed the use of standard IAP (OR 0.318, 95\% CI 0.118-0.862; $p=0.024$ ) as a predictor of less intra-operative complications and moderate NMB (OR 3.518, 95\% CI 1.244-9.948; $p=$ 0.018 ) as a significant predictor of more intra-operative complications. All graded $\geq 2$ according to ClassIntra (Table 3).

Thirty-one (6.8\%) postoperative complications with grade $\geq 2$ according to the Clavien-Dindo classification were noted (Table 4). Chi-square analysis and multiple logistic regression analysis did not show a significant association between IAP or NMB as independent predictors of postoperative complications (Tables 3 and 4).

Logistic regression analysis did not show a significant association between intra-operative complications, graded $\geq 2$ according to ClassIntra, and postoperative complications according to Clavien-Dindo classification graded $\geq 2$ (OR 0.181, 95\% CI 0.407-3.532; $p=0.742$ ).

\section{Other outcomes}

Linear regression analysis on other outcomes is presented in Table 5. The estimated blood loss was significantly lower with standard IAP and higher with moderate NMB as well as within males (resp. $\beta 0.240, p$ $=0.000 ; \beta-0.219, p=0.000$; and $\beta-0.088, p=0.034$ ). With standard IAP, moderate NMB, and within males, operation time was significantly longer (resp. $\beta-0.074, p$

Table 2 Intra-operative complications according to ClassIntra grade $\geq 2$ and other intra-operative variables

\begin{tabular}{|c|c|c|c|c|}
\hline & A & B & $\mathrm{C}$ & D \\
\hline Intra-abdominal pressure ${ }^{g}$ & Standard & Standard & Low & Low \\
\hline \multirow[t]{2}{*}{ Neuromuscular blockade ${ }^{\mathrm{h}}$} & Moderate & Deep & Moderate & Deep \\
\hline & $(n=401)$ & $(n=78)$ & $(n=29)$ & $(n=48)$ \\
\hline \multicolumn{5}{|c|}{ Intra-operative complications (ClassIntra grade $\geq 2$ ) } \\
\hline Total number & $32(8.0 \%)^{a, d, e}$ & $2(2.6 \%)^{a, c, f}$ & $11(37.9 \%)^{b, c, e}$ & $8(16.7 \%)^{b, d, f}$ \\
\hline Grade 2 & $30(7.5 \%)$ & $2(2.6 \%)$ & $10(34.5 \%)$ & $8(16.7 \%)$ \\
\hline Grade 3 & $2(0.5 \%)$ & $0(0.0 \%)$ & $0(0.0 \%)$ & $0(0.0 \%)$ \\
\hline Grade 4 & $0(0.0 \%)$ & $0(0.0 \%)$ & $1(3.4 \%)$ & $0(0.0 \%)$ \\
\hline \multicolumn{5}{|l|}{ Type of complication } \\
\hline Bleeding & $13(40.6 \%)$ & $2(100 \%)$ & $10(90.9 \%)$ & $7(87.5 \%)$ \\
\hline Organ laceration & $16(50.0 \%)$ & $0(0.0 \%)$ & $1(9.1 \%)$ & $1(12.5 \%)$ \\
\hline Bleeding and organ laceration & $2(6.3 \%)$ & $0(0.0 \%)$ & $0(0.0 \%)$ & $0(0.0 \%)$ \\
\hline Other ${ }^{i}$ & $1(3.1 \%)$ & $0(0.0 \%)$ & $0(0.0 \%)$ & $0(0.0 \%)$ \\
\hline Operation time (min) & $210.5( \pm 73.7)$ & $130.4( \pm 41.8)$ & $155.2( \pm 39.9)$ & $119.7( \pm 33.2)$ \\
\hline Estimated blood loss (ml) & $62.3( \pm 69.6)$ & $45.8( \pm 58.7)$ & $245.7( \pm 499.8)$ & $76.1( \pm 128.5)$ \\
\hline Conversion to open procedure & $2(3.4 \%)$ & $1(1.3 \%)$ & $4(13.8 \%)$ & $3(6.3 \%)$ \\
\hline
\end{tabular}

Chi-square testing: ${ }^{\mathrm{a}} \mathrm{A}$ vs $\mathrm{B}, p=0.088 ;{ }^{\mathrm{b}} \mathrm{C}$ vs $\mathrm{D}, p=0.109 ;{ }^{\mathrm{C}} \mathrm{B}$ vs $\mathrm{C}, p<0.001 ;{ }^{\mathrm{d}} \mathrm{A}$ vs $\mathrm{D}, p=0.076 ;{ }^{\mathrm{e}} \mathrm{A}$ vs $\mathrm{C}, p<0.001 ;{ }^{\mathrm{f}} \mathrm{B}$ vs $\mathrm{D}, p=0.009$

${ }^{9}$ Standard pressure 12-14 $\mathrm{mmHg}$; low pressure 6-7 $\mathrm{mmHg}$

${ }^{\mathrm{h}}$ Moderate blockade: single dose rocuronium or TOF count 1-2; deep blockade: PTC 1-2 or PTC 1-5

'Re-laparoscopic procedure for lost gauze $(1 \times)$ 
Table 3 Multiple logistic regression model with intra-operative complications (Classlntra grade $\geq 2$ ) and postoperative complications (Clavien-Dindo grade $\geq 2$ )

\begin{tabular}{|c|c|c|c|c|}
\hline Dependent & Predictors & $B$ & OR $(C l)$ & $p$ \\
\hline \multirow[t]{6}{*}{ Intra-operative complications (ClassIntra grade $\geq 2$ ) } & IAP (standard) & -1.145 & $0.318(0.118-0.862)$ & 0.024 \\
\hline & NMB (moderate) & 1.258 & $3.518(1.244-9.948)$ & 0.018 \\
\hline & Gender (male) & 0.380 & $1.462(0.759-2.816)$ & 0.256 \\
\hline & Age & 0.024 & $1.024(0.997-1.052)$ & 0.085 \\
\hline & $\mathrm{BMI}$ & -0.002 & $0.998(0.912-1.092)$ & 0.963 \\
\hline & Trial year & 0.217 & $1.242(0.602-2.562)$ & 0.558 \\
\hline \multirow[t]{6}{*}{ Postoperative complications (Clavien-Dindo grade $\geq 2$ ) } & IAP (standard) & 0.493 & $1.638(0.513-5.234)$ & 0.405 \\
\hline & NMB (moderate) & -0.446 & $0.640(0.274-1.498)$ & 0.304 \\
\hline & Gender (male) & 0.198 & $1.219(0.606-2.450)$ & 0.579 \\
\hline & Age & 0.005 & $1.005(0.976-1.035)$ & 0.747 \\
\hline & $\mathrm{BMI}$ & -0.037 & $0.964(0.870-1.068)$ & 0.484 \\
\hline & Trial year & 0.684 & $1.982(0.828-4.744)$ & 0.124 \\
\hline
\end{tabular}

$=0.049 ; \beta-0.236, p=0.000$; and $\beta-0.106, p=0.002$ ). Trial year was a significant predictor of operation time $(\beta-0.419 ; p=0.000)$. The length of hospital admission was also significantly shorter in the trials conducted in more recent years (resp. $\beta-0.157 ; p=0.007$ ).

\section{Discussion}

This analysis shows an incidence of fifty-three (9.5\%) intra-operative complications grade $\geq 2$ according to ClassIntra(Dell-Kuster et al., 2020) in 556 patients undergoing laparoscopic donor nephrectomy. Deep NMB was a significant predictor for less intra-operative complications. Four of the listed studies investigated the relationship between the depth of NMB and/or IAP, clinical outcomes, and intra-operative complications in laparoscopic donor nephrectomy (LDN). One study indicates that the use of low pressure could lead to lower pain scores and a better recovery after LDN(Warlé et al., 2013), but this could not be confirmed by another tria1.(Özdemir-van Brunschot et al., 2017) Moreover, it has been shown that the use of low pressure with moderate NMB may compromise safety, (Özdemir-van Brunschot et al., 2018) where two studies indicate that the use of a deep NMB improves intra-operative safety during low and standard pressure LDN.(Özdemir-van Brunschot et al., 2018; Bruintjes et al., 2019) An earlier metaanalysis(Bruintjes et al., 2017) showed the surgical working field was significantly improved during laparoscopic

Table 4 Postoperative complications (Clavien-Dindo grade $\geq 2$ ) and hospital admission

\begin{tabular}{|c|c|c|c|c|}
\hline & A & B & C & D \\
\hline Intra-abdominal pressure ${ }^{g}$ & Standard & Standard & Low & Low \\
\hline \multirow[t]{2}{*}{ Neuromuscular blockade ${ }^{\mathrm{h}}$} & Moderate & Deep & Moderate & Deep \\
\hline & $(n=298)$ & $(n=78)$ & $(n=29)$ & $(n=48)$ \\
\hline \multicolumn{5}{|c|}{ Postoperative complications (Clavien-Dindo grade $\geq 2$ ) } \\
\hline Total number & $17(5.7 \%)^{\mathrm{a}, \mathrm{d}, \mathrm{e}}$ & $9(11.5 \%)^{\mathrm{a}, \mathrm{c}, \mathrm{f}}$ & $2(6.9 \%)^{b, c, e}$ & $3(6.3 \%)^{b, d, f}$ \\
\hline Grade 2 & $17(5.7 \%)$ & $9(11.5 \%)$ & $2(6.9 \%)$ & $2(4.2 \%)$ \\
\hline Grade 3 & $0(0.0 \%)$ & $0(0.0 \%)$ & $0(0.0 \%)$ & $1(2.1 \%)$ \\
\hline \multicolumn{5}{|l|}{ Type of complication } \\
\hline Infection & $8(47.1 \%)$ & $7(77.8 \%)$ & $0(0.0 \%)$ & $0(0.0 \%)$ \\
\hline Bleeding & $3(17.6 \%)$ & $0(0.0 \%)$ & $0(0.0 \%)$ & $0(0.0 \%)$ \\
\hline Ileus/gastroparesis & $2(11.8 \%)$ & $1(11.1 \%)$ & $0(0.0 \%)$ & $1(33.3 \%)$ \\
\hline Other' & $4(23.5 \%)$ & $1(11.1 \%)$ & $2(100 \%)$ & $2(66.7 \%)$ \\
\hline Length of hospital admission (days) & $4.0( \pm 0.9)$ & $3.7( \pm 1.0)$ & $4.7( \pm 1.3)$ & $3.9( \pm 1.3)$ \\
\hline
\end{tabular}

Chi square testing: ${ }^{\mathrm{a}} \mathrm{A}$ vs $\mathrm{B}, p=0.097 ;{ }^{\mathrm{b}} \mathrm{C}$ vs $\mathrm{D}, p=0.917 ;{ }^{\mathrm{C}} \mathrm{B}$ vs $\mathrm{C}, p=0.522 ;{ }^{\mathrm{d}} \mathrm{A}$ vs $\mathrm{D}, p=0.887 ;{ }^{\mathrm{e}} \mathrm{A}$ vs $\mathrm{C}, p=0.806 ;{ }^{\mathrm{f}} \mathrm{B}$ vs $\mathrm{D}, p=0.369$

${ }^{9}$ Standard pressure 12-14 $\mathrm{mmHg}$; low pressure 6-7 $\mathrm{mmHg}$

${ }^{\mathrm{h}}$ Moderate blockade: single dose rocuronium or TOF count 1-2; deep blockade: PTC 1-2 or PTC 1-5

'Hypertension ( $3 \times)$, atrial fibrillation/supraventricular tachycardia $(2 \times)$, pneumothorax $(1 \times)$, meatus stenosis $(1 \times)$, respiratory insufficiency, no diagnosis reported $(1 \times)$, subcutaneous emphysema $(1 \times)$ 
Table 5 Multiple linear regression on other outcomes

\begin{tabular}{|c|c|c|c|c|}
\hline Dependent & Predictors & $B$ & Beta coefficient $(C l)$ & $p$ \\
\hline \multirow[t]{6}{*}{ Estimated blood loss } & IAP (standard) & 87.499 & $0.240(54.694-120.304)$ & 0.000 \\
\hline & NMB (moderate) & -66.039 & $-0.219(-94.590$ to -37.488$)$ & 0.000 \\
\hline & Gender (male) & -22.375 & $-0.088(-43.047$ to -1.703$)$ & 0.034 \\
\hline & Age & 0.338 & $0.032(-0.523-1.198)$ & 0.441 \\
\hline & BMl & -0.232 & $-0.007(-3.088-2.625)$ & 0.874 \\
\hline & Trial year & 3.505 & $0.014(-20.464-27.474)$ & 0.774 \\
\hline \multirow[t]{6}{*}{ Operation time } & IAP (standard) & -16.042 & $-0.074(-32.045$ to -0.039$)$ & 0.049 \\
\hline & NMB (moderate) & -42.115 & $-0.236(-56.042$ to -28.188$)$ & 0.000 \\
\hline & Gender (male) & -15.932 & $-0.106(-26.016$ to -5.848$)$ & 0.002 \\
\hline & Age & 0.045 & $0.007(-0.375-0.465)$ & 0.834 \\
\hline & BMl & 0.577 & $0.028(-0.816-1.971)$ & 0.416 \\
\hline & Trial year & -63.773 & $-0.419(-75.465$ to -52.081$)$ & 0.000 \\
\hline \multirow[t]{6}{*}{ Length of hospital admission } & IAP (standard) & -0.052 & $-0.021(-0.485-0.381)$ & 0.812 \\
\hline & NMB (moderate) & -0.280 & $-0.128(-0.610-0.050)$ & 0.096 \\
\hline & Gender (male) & 0.070 & $0.033(-0.240-0.379)$ & 0.658 \\
\hline & Age & 0.004 & $0.041(-0.010-0.019)$ & 0.584 \\
\hline & $\mathrm{BMl}$ & -0.015 & $-0.044(-0.066-0.035)$ & 0.549 \\
\hline & Trial year & -0.157 & $-0.237(-0.270$ to -0.043$)$ & 0.007 \\
\hline
\end{tabular}

surgeries facilitated by a deep NMB as compared with a moderate NMB. Therefore, a lower incidence of surgical complications during laparoscopic surgery with a deep NMB is in line with existing literature.(Torensma et al., 2016; Bruintjes et al., 2017; Özdemir-van Brunschot et al., 2018; Martini et al., 2014; Kim et al., 2016; Koo et al., 2016; Yoo et al., 2015; Dubois et al., 2014; Staehr-Rye et al., 2014) Additionally, a recent randomized controlled trial in patients undergoing gastric bypass surgery showed that poor surgical conditions were associated with a higher incidence of intra-operative surgical complications $(61.5 \%$ in the moderate block versus $15.3 \%$ in the deep NMB block; $p<$ 0.001).(Fuchs-Buder et al., 2019) These findings support the beneficial influence of a deep NMB on the risk of intraoperative complications. Maintaining a deep NMB until the end of surgery challenges the anesthetic team, since adequate neuromuscular monitoring is required, which can be challenging if the arms cannot be positioned in abduction. Moreover, additional training may be required for adequate continuous perfusion of a neuromuscular blocking agent, dose adjustments and the use of antagonizing agents (i.e. sugammadex) to prevent residual NMB. Preventing residual NMB decreases the risk of postoperative pulmonary complications (Cammu, 2020). Furthermore, the costs related to the use of antagonizing agents can be a hurdle in routine practice. Given these challenges, a higher level of evidence is warranted, necessitating a prospective randomized clinical trial to confirm the hypothesis that the use of deep NMB reduces intra-operative complications, thereby improving patient safety.
Although consensus guidelines from the Dutch and European Societies of Endoscopic Surgery(Neudecker et al., 2002; la Chapelle et al., 2012) state that the lowest possible IAP with an adequate surgical field should be used, a vast majority of laparoscopic surgeons use a routine insufflation pressure of $\geq 12 \mathrm{mmHg}$. Probably, the main reason for this is that the use of low IAP $(<10$ $\mathrm{mmHg}$ ) may hamper the quality of the surgical field. Our data confirm that low IAP was not associated with an increased risk of intra-operative complications. This indicates that the stepwise increase of IAP in case of inadequate surgical conditions is a safe approach to apply low IAP if possible, during LDN. Therefore, our data support the above-mentioned guidelines regarding the use of a low IAP.

In this study, we found no relationship between intraand postoperative complications, which is not fully in line with findings in earlier published trials. Bohnen et al.(Bohnen et al., 2017) showed, among patients undergoing abdominal surgery, that intra-operative complications were independently associated with an approximately 3 -fold increase in 30-day postoperative complications and increased length of hospital admission.(Bohnen et al., 2017; Hu et al., 2012; Boon et al., 2018) A recent large validation study of the IntraClass by Dell-Kuster et al. among 2520 patients undergoing any type of surgery clearly demonstrated a strong correlation between intra- and postoperative complications (Dell-Kuster et al., 2020), especially more severe intra-operative complications graded 3 and 4 correlated 
with postoperative complications. In the studies included for this pooled analysis, only grade 2 intra-operative complications were observed. This may very well explain why we could not find this relationship between intraand postoperative complications. With cumulating evidence indicating an association between intra-operative complications and 30-day postoperative mortality, postoperative morbidity, and length of hospital admission,(Kinaci et al., 2016; Dell-Kuster et al., 2020; Bohnen et al., 2017; Hu et al., 2012; Boon et al., 2018) a prospective, randomized trial is required to establish a possible relationship between the use of deep NMB and a lower incidence of postoperative complications after laparoscopic surgery.

A strength of this study is the inclusion of relatively healthy individuals undergoing a highly standardized surgical procedure, performed in academic teaching hospitals throughout the Netherlands. This contributed to a relatively high internal validity of the trials used for the pooled analysis. All ClassIntra grade $\geq 2$ intra-operative complications were prospectively recorded by a doubleblinded observer which reduces the risk of observer bias. Moreover, our pooled analysis of individual patient data allowed us to perform multiple variable regression analyses to identify independent predictors of intraoperative complications.

The retrospective nature of the pooled, individual patient, data analysis is a limitation of this study. These trials were not powered or designed to study the effect of $\mathrm{NMB}$ or IAP on the risk of intra-operative complications. Therefore, a certain degree of confounding bias cannot be ruled out. Another limitation of this study is the intra-operative complications were graded retrospectively by three blinded researchers (EH, GRB, and MW) according to the ClassIntra classification for intraoperative complications. This classification was proposed by Dell-Kuster et al.(Dell-Kuster et al., 2020) and was developed to grade all patient-related intra-operative complications including all deviations from the ideal intra-operative course.(Dell-Kuster et al., 2015; DellKuster et al., 2020) An underreporting of small complications with intervention is understandable, and minor deviations from the ideal course without the need for an additional intervention (ClassIntra grade 1) were not actively recorded. The low event rate is another limitation of this study which leads to the need for large randomized clinical trials with a higher event rate to confirm our findings. Moreover, the included studies vary from 2001 to 2017. The learning curve not only of individual surgeons, but also of the whole team (or center) could have been a potential source of bias.

In conclusion, our data indicate that the use of a deep $\mathrm{NMB}$ increases safety during laparoscopic donor nephrectomy, when compared with moderate NMB. The use of low IAP with a stepwise increase in case of inadequate surgical conditions was not associated with an increased risk of intra-operative complications and may therefore be a safe strategy for using lower insufflation pressures. The EURO-relax trial(GHM et al., 2021) will reveal if the routine use of deep NMB throughout laparoscopic surgery decreases intra- and postoperative complications and thereby improves patient safety.

\section{Abbreviations \\ IAP: Intra-abdominal pressure; NMB: Neuromuscular blockade; TOF: Train of four; PTC: Post-tetanic count}

\section{Acknowledgements}

The authors thank all the collaborators of the Radboudumc and the Erasmus MC study groups for their contribution to this manuscript.

\section{Authors' contributions}

All authors contributed in collecting data in one or more of the included randomized controlled trials. GRB, EH, and MW pooled and analyzed the data. All authors contributed in writing the manuscript. The authors read and approved the final manuscript.

\section{Funding}

This pooled analysis did not receive any specific grant from funding agencies in the public, commercial, or not-for-profit sectors. Funding for the original clinical trials was disclosed in the primary publications.

Availability of data and materials

The pooled dataset analyzed during this study is available from the corresponding author on reasonable request.

\section{Declarations}

Ethics approval and consent to participate

Approval for the trials was given by the local ethics committee of each center as stated under the section "Ethics." Oral and written informed consent was obtained from all patients before inclusion in all trials.

\section{Consent for publication}

All authors gave consent for publication.

\section{Competing interests}

The authors declare that they have no competing interests.

\section{Author details}

${ }^{1}$ Department of Surgery, Radboud University Medical Centre, Geert Grooteplein Zuid 10, 6525, GA, Nijmegen, The Netherlands. ${ }^{2}$ Department of Anaesthesiology, Radboud University Medical Centre, Geert Grooteplein Zuid 10, 6525, GA, Nijmegen, The Netherlands. ${ }^{3}$ Department of Surgery, Erasmus Medical Centre, Doctor Molewaterplein 40, 3015, GD, Rotterdam, The Netherlands. ${ }^{4}$ Department of Anaesthesiology, Leiden University Medical Centre, Albinusdreef 2, 2333, ZA, Leiden, The Netherlands. ${ }^{5}$ Department of Urology, Radboud University Medical Centre, Geert Grooteplein Zuid 10, 6525, GA, Nijmegen, The Netherlands.

Received: 4 June 2021 Accepted: 30 September 2021

Published online: 09 December 2021

\footnotetext{
References

Albers Kl, Díaz Cambronero O, Keijzer C, Snoeck MMJ, Warlé MC, Fuchs-Buder T. Revisiting the classification of neuromuscular blockade, aligning clinical practice and research. Anesth Analg. 2019;129(5):e176-e8. https://doi.org/1 0.1213/ANE.0000000000004407.

Blobner M, Frick CG, Stauble RB, Feussner H, Schaller SJ, Unterbuchner C, et al. Neuromuscular blockade improves surgical conditions (NISCO). Surg Endosc. 2015;29(3):627-36. https://doi.org/10.1007/s00464-014-3711-7.

Bohnen JD, Mavros MN, Ramly EP, Chang Y, Yeh DD, Lee J, et al. Intraoperative adverse events in abdominal surgery: what happens in the operating room
} 
does not stay in the operating room. Ann Surg. 2017;265(6):1119-25. https:// doi.org/10.1097/SLA.0000000000001906.

Boon M, Martini C, Yang HK, Sen SS, Bevers R, Warlé M, et al. Impact of highversus low-dose neuromuscular blocking agent administration on unplanned 30-day readmission rates in retroperitoneal laparoscopic surgery. PLoS One. 2018;13(5):e0197036. https://doi.org/10.1371/journal.pone.0197036.

Bruintjes MH, van Helden EV, Braat AE, Dahan A, Scheffer GJ, van Laarhoven CJ, et al. Deep neuromuscular block to optimize surgical space conditions during laparoscopic surgery: a systematic review and meta-analysis. $\mathrm{Br}$ Anaesth. 2017;118(6):834-42. https://doi.org/10.1093/bja/aex116.

Bruintjes MHD, Krijtenburg P, Martini CH, Poyck PP, d'Ancona FCH, Huurman VAL, et al. Efficacy of profound versus moderate neuromuscular blockade in enhancing postoperative recovery after laparoscopic donor nephrectomy: a randomised controlled trial. Eur J Anaesthesiol. 2019;36(7):494-501. https:// doi.org/10.1097/EJA.0000000000000992.

Cammu G. Residual neuromuscular blockade and postoperative pulmonary complications: what does the recent evidence demonstrate? Curr Anesthesiol Rep. 2020;10(2):131-6. https://doi.org/10.1007/s40140-020-003 88-4.

Dell-Kuster S, Clavien PA, Bucher HC, Rosenthal R. Classification of intraoperative complications: reply. World J Surg. 2015;39(12):3033-4. https://doi.org/10.1 007/s00268-015-3199-x

Dell-Kuster S, Gomes NV, Gawria L, Aghlmandi S, Aduse-Poku M, Bissett I, et al. Prospective validation of classification of intraoperative adverse events (ClassIntra): international, multicentre cohort study. BMJ. 2020;370:m2917.

Dindo D, Demartines N, Clavien PA. Classification of surgical complications: a new proposal with evaluation in a cohort of 6336 patients and results of a survey. Ann Surg. 2004;240(2):205-13. https://doi.org/10.1097/01.sla.0000133 083.54934.ae.

Dols LF, Kok NF, d'Ancona FC, Klop KW, Tran TC, Langenhuijsen JF, et al. Randomized controlled trial comparing hand-assisted retroperitoneoscopic versus standard laparoscopic donor nephrectomy. Transplantation. 2014; 97(2):161-7. https://doi.org/10.1097/TP.0b013e3182a902bd.

Dols LF, Kok NF, Terkivatan T, Tran KT, Alwayn IP, Weimar W, et al. Optimizing left-sided live kidney donation: hand-assisted retroperitoneoscopic as alternative to standard laparoscopic donor nephrectomy. Transpl Int. 2010; 23(4):358-63. https://doi.org/10.1111/j.1432-2277.2009.00990.x.

Dubois PE, Putz L, Jamart J, Marotta ML, Gourdin M, Donnez O. Deep neuromuscular block improves surgical conditions during laparoscopic hysterectomy: a randomised controlled trial. Eur J Anaesthesiol. 2014;31(8): 430-6. https://doi.org/10.1097/EJA.0000000000000094.

Fuchs-Buder T, Schmartz D, Baumann C, Hilt L, Nomine-Criqui C, Meistelman C, et al. Deep neuromuscular blockade improves surgical conditions during gastric bypass surgery for morbid obesity: a randomised controlled trial. Eur J Anaesthesiol. 2019;36(7):486-93. https:/doi.org/10.1097/EJA.0000000000000996.

Honing GHM, Reijnders-Boerboom GTJA, Dell-Kuster S, Van Velzen M, Martini CH, Valenza F, Proto P, Díaz Cambronero O, Broens S, Panhuizen I, Roozekrans M, Fuchs-Buder T, Boon M, Dahan A, Warlé MC. The impact of deep versus standard neuromuscular block on intra-operative safety during laparoscopic surgery: an international multicenter randomized controlled double-blind strategy trial (EURO-RELAX). Trials 2021;22:744. https://doi.org/10.1186/s13 063-021-05638-2.

Gurusamy KS, Samraj K, Davidson BR. Low pressure versus standard pressure pneumoperitoneum in laparoscopic cholecystectomy. Cochrane Database Syst Rev. 2009;(2):Cd006930. https://doi.org/10.1002/14651858.CD006930.pub2.

Hu YY, Arriaga AF, Roth EM, Peyre SE, Corso KA, Swanson RS, et al. Protecting patients from an unsafe system: the etiology and recovery of intraoperative deviations in care. Ann Surg. 2012;256(2):203-10. https://doi.org/10.1097/SLA. ob013e3182602564

Kaafarani HM, Velmahos GC. Classification of intraoperative complications. World J Surg. 2015;39(12):3032. https://doi.org/10.1007/s00268-015-3119-0.

Kim MH, Lee KY, Lee KY, Min BS, Yoo YC. Maintaining optimal surgical conditions with low insufflation pressures is possible with deep neuromuscular blockade during laparoscopic colorectal surgery: a prospective, randomized, double-blind, parallel-group clinical trial. Medicine. 2016;95(9):e2920. https:// doi.org/10.1097/MD.0000000000002920.

Kinaci E, Sevinc MM, Bayrak S, Erdogan E, Ozakay A, Sari S. Is the classification of intraoperative complications (CLASSIC) related to postoperative course? Int J Surgery (London, England). 2016;29:171-5.

Klop KW, Kok NF, Dols LF, Dor FJ, Tran KT, Terkivatan T, et al. Can right-sided hand-assisted retroperitoneoscopic donor nephrectomy be advocated above standard laparoscopic donor nephrectomy: a randomized pilot study. Transpl Int. 2014;27(2):162-9. https://doi.org/10.1111/tri.12226.

Kok NF, Alwayn IP, Lind MY, Tran KT, Weimar W, JN IJ. Donor nephrectomy: miniincision muscle-splitting open approach versus laparoscopy. Transplantation. 2006a;81 (6):881-7. https://doi.org/10.1097/01.tp.0000203320.74256.fd.

Kok NF, Lind MY, Hansson BM, Pilzecker D, Mertens zur Borg IR, Knipscheer BC, et al. Comparison of laparoscopic and mini incision open donor nephrectomy: single blind, randomised controlled clinical trial. BMJ. 2006b; 333(7561):221. https://doi.org/10.1136/bmj.38886.618947.7C.

Koo BW, Oh AY, Seo KS, Han JW, Han HS, Yoon YS. Randomized clinical trial of moderate versus deep neuromuscular block for low-pressure pneumoperitoneum during laparoscopic cholecystectomy. World J Surg. 2016;40(12):2898-903. https://doi.org/10.1007/s00268-016-3633-8.

la Chapelle CF, Bemelman WA, Rademaker BM, van Barneveld TA, Jansen FW. A multidisciplinary evidence-based guideline for minimally invasive surgery: part 1: entry techniques and the pneumoperitoneum. Gynecol Surg. 2012; 9(3):271-82. https://doi.org/10.1007/s10397-012-0731-y.

Lindekaer AL, Halvor Springborg H, Istre O. Deep neuromuscular blockade leads to a larger intraabdominal volume during laparoscopy. J Vis Exp. 2013;76(76): 50045. https://doi.org/10.3791/50045.

Madsen MV, Gatke MR, Springborg HH, Rosenberg J, Lund J, Istre O. Optimising abdominal space with deep neuromuscular blockade in gynaecologic laparoscopy--a randomised, blinded crossover study. Acta Anaesthesiol Scand. 2015;59(4):441-7. https://doi.org/10.1111/aas.12493.

Martini CH, Boon M, Bevers RF, Aarts LP, Dahan A. Evaluation of surgical conditions during laparoscopic surgery in patients with moderate vs deep neuromuscular block. Br J Anaesth. 2014;112(3):498-505. https://doi.org/10.1 093/bja/aet377.

Minnee RC, Bemelman WA, Maartense S, Bemelman FJ, Gouma DJ, Idu MM. Left or right kidney in hand-assisted donor nephrectomy? A randomized controlled trial. Transplantation. 2008;85(2):203-8. https://doi.org/10.1097/TP. ob013e3181601486.

Mitropoulos D, Artibani W, Biyani CS, Bjerggaard Jensen J, Roupret M, Truss M. Validation of the Clavien-Dindo grading system in urology by the European Association of Urology guidelines ad hoc panel. Eur Urol Focus. 2018;4(4): 608-13. https://doi.org/10.1016/..euf.2017.02.014.

Neudecker J, Sauerland S, Neugebauer E, Bergamaschi R, Bonjer HJ, Cuschieri A, et al. The European Association for Endoscopic Surgery clinical practice guideline on the pneumoperitoneum for laparoscopic surgery. Surg Endosc. 2002;16(7):1121-43. https://doi.org/10.1007/s00464-001-9166-7.

Özdemir-van Brunschot DM, van Laarhoven KC, Scheffer GJ, Pouwels S, Wever KE, Warlé MC. What is the evidence for the use of low-pressure pneumoperitoneum? A systematic review. Surg Endosc. 2016;30(5):2049-65. https://doi.org/10.1007/s00464-015-4454-9.

Özdemir-van Brunschot DMD, Braat AE, van der Jagt MFP, Scheffer GJ, Martini $\mathrm{CH}$, Langenhuijsen JF, et al. Deep neuromuscular blockade improves surgical conditions during low-pressure pneumoperitoneum laparoscopic donor nephrectomy. Surg Endosc. 2018;32(1):245-51. https://doi.org/10.1007/s004 64-017-5670-2.

Özdemir-van Brunschot DMD, Scheffer GJ, van der Jagt M, Langenhuijsen $H$, Dahan A, Mulder J, et al. Quality of recovery after low-pressure laparoscopic donor nephrectomy facilitated by deep neuromuscular blockade: a randomized controlled study. World J Surg. 2017;41(11):2950-8. https://doi. org/10.1007/s00268-017-4080-x.

Pansard JL, Chauvin M, Lebrault C, Gauneau P, Duvaldestin P. Effect of an intubating dose of succinylcholine and atracurium on the diaphragm and the adductor pollicis muscle in humans. Anesthesiology. 1987;67(3):326-30. https://doi.org/10.1097/00000542-198709000-00008.

Rosenthal R, Hoffmann H, Clavien PA, Bucher HC, Dell-Kuster S. Definition and classification of intraoperative complications (CLASSIC): Delphi study and pilot evaluation. World J Surg. 2015;39(7):1663-71. https://doi.org/10.1007/s00268-015-3003-y.

Singla S, Mittal G, Raghav, Mittal RK. Pain management after laparoscopic cholecystectomy-a randomized prospective trial of low pressure and standard pressure pneumoperitoneum. J Clin Diagn Res 2014;8(2):92-94.

Staehr-Rye AK, Rasmussen LS, Rosenberg J, Juul P, Lindekaer AL, Riber C, et al. Surgical space conditions during low-pressure laparoscopic cholecystectomy with deep versus moderate neuromuscular blockade: a randomized clinical study. Anesth Analg. 2014;119(5):1084-92. https://doi.org/10.1213/ANE. 0000000000000316

Torensma B, Martini CH, Boon M, Olofsen E, In't Veld B, Liem RS, et al. Deep neuromuscular block improves surgical conditions during bariatric surgery 
and reduces postoperative pain: a randomized double-blind controlled trial. PLoS One. 2016;11(12):e0167907.

Van Wijk RM, Watts RW, Ledowski T, Trochsler M, Moran JL, Arenas GW. Deep neuromuscular block reduces intra-abdominal pressure requirements during laparoscopic cholecystectomy: a prospective observational study. Acta Anaesthesiol Scand. 2015;59(4):434-40. https://doi.org/10.1111/aas.12491.

Warlé MC, Berkers AW, Langenhuijsen JF, van der Jagt MF, Dooper PM, Kloke HJ, et al. Low-pressure pneumoperitoneum during laparoscopic donor nephrectomy to optimize live donors' comfort. Clin Transplant. 2013;27(4): E478-83. https://doi.org/10.1111/ctr.12143.

Yoo YC, Kim NY, Shin S, Choi YD, Hong JH, Kim CY, et al. The intraocular pressure under deep versus moderate neuromuscular blockade during low-pressure robot assisted laparoscopic radical prostatectomy in a randomized trial. PLoS One. 2015;10(8):e0135412. https://doi.org/10.1371/journal.pone.0135412.

\section{Publisher's Note}

Springer Nature remains neutral with regard to jurisdictional claims in published maps and institutional affiliations.

Ready to submit your research? Choose BMC and benefit from:

- fast, convenient online submission

- thorough peer review by experienced researchers in your field

- rapid publication on acceptance

- support for research data, including large and complex data types

- gold Open Access which fosters wider collaboration and increased citations

- maximum visibility for your research: over $100 \mathrm{M}$ website views per year

At BMC, research is always in progress.

Learn more biomedcentral.com/submissions 